\title{
ORIGIN OF THE THERMAL WATERS IN THE YELLOWSTONE NATIONAL PARK ${ }^{1}$
}

ANNOAL ADDRESS OF THE PRESIDENT, ARNOLD HAGUE

(Read before the Society December 27, 1910)

CONTENTS

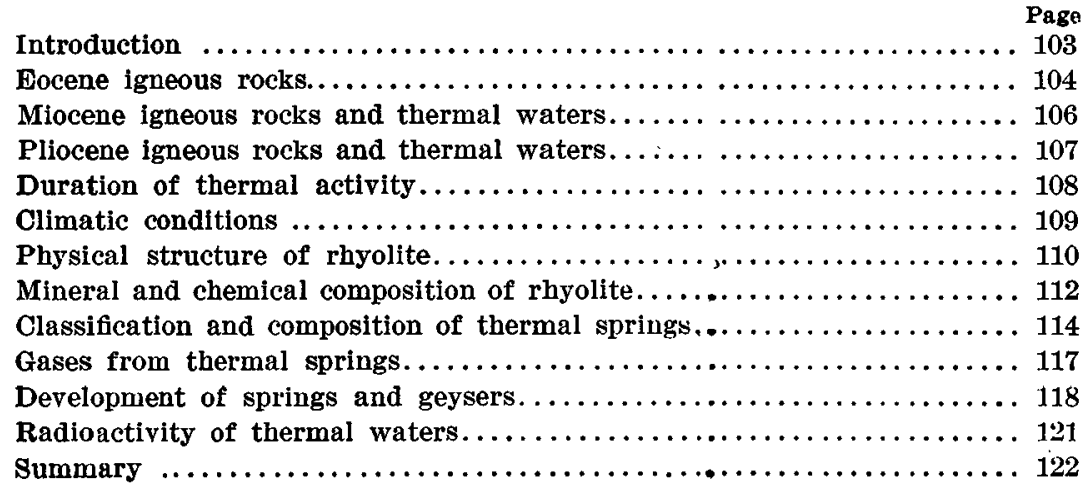

\section{INTRODUCTION}

From the earliest days of systematic geological research thermal springs have been a frequent subject of investigations by students of natural phenomena. From time to time numerous contributions to scientific literature bearing on the nature of hot springs, partly descriptive and in part theoretical, have been presented to learned societies. Nearly all regions where such waters issue from the ground on an imposing scale appear to have been at one time or another scenes of eruptive energy. In so many instances has this been shown to be the case that thermal activity and volcanic manifestations have come to be regarded as associated phenomena. It by no means follows, however, that the original source of all these waters was, geologically speaking, deep-seated, and by a large school of geologists it has never been so regarded. In recent years the results of several suggestive researches have been published, in which the position

1 Manuscript received by the Secretary of the Socfety January 17, 1011. 
is taken that superheated waters issuing from igneous rocks are primitive in their origin - that is to say, they are derived from great depths in the earth's crust and are brought to the surface for the first time by volcanic forces.

The Yellowstone National Park affords one of the most remarkable, and probably one of the most instructive, areas of thermal springs and geysers to be found in the world. The varied phenomena of boiling springs and aqueous vapors there stand unsurpassed. Several years ago, after a study of the region under the auspices of the United States Geological Survey, I published in official documents, and later in Johnson's Universal Cyclopædia, an article entitled "Thermal Springs," in which I stated the conclusion that the waters of these hot springs and geysers were essentially meteoric waters that had penetrated downwards a suffcient distance to attain an increased temperature, only to be forced again to the surface by ascending currents.

I propose on this occasion to present briefly some of the geological evidence on which these conclusions are founded. They are based on the nature and structure of the rocks through which the heated waters reach the surface, the mineral constituents contained in the waters, the composition of the associated gases, and the characters of the varied sediments and incrustations deposited around the springs and pools.

\section{Eocene Ianeous Rooks}

To understand correctly the relations of the thermal waters found in the park to existing geological conditions, a brief history of the salient features of its igneous rocks and their sequence seems necessary. The country included within the Yellowstone Park, the Absaroka Range, and the Wind River Plateau consists essentially of masses of igneous rocks covering an area of over 5,000 square miles in the center of a continent whose three great rivers, the Mississippi, the Colorado, and the Columbia, here find their source. Within this region, through that vast period of time from the close of the Archean to the dawn of the Tertiary, all evidences of eruptive energy are wanting. Coincident with the earliest indications of the post-Laramie orogenic movement came a period of intrusion which began in late Cretaceous time and continued with only slight periods of rest till near the end of the Pliocene. Whatever the primary causes were that produced this orogenic movement, the enlargement of the continental area, and the final withdrawal of the sea, they brought about mountain uplifts, crustal displacements, and volcanic activities of the first magnitude. The close of the Cretaceous in this part of the northern Cordillera was marked by the most profound strati- 
graphic break since Algonkian time. The oldest intrusives, recognized as such, are found in the northwestern corner of the Yellowstone Park in what is now the Gallatin Range, and inaugurated a physical revolution. These rocks were forced in as sills between Upper Mesozoic sandstones before the latter were much disturbed, as they lie unconformably interbedded between sediments which later were affected by the dynamic processes of mountain elevation. In this sense these earliest intrusions must be considered, structurally at least, as of Cretaceous age. They were succeeded by more powerful injections, accompanied by slow and protracted elevation of the Gallatin Range. With the emergence of land surfaces erosion followed and sediments were deposited unconformably. Elevation of mountain masses produced new physiographic features, and as a consequence changes in climatic conditions and modifications of living species, both animal and vegetable. The Tertiary period was ushered in. With the progressive building up of the range and the associated folding and compression of strata, viscous magmas were injected from unknown depths. Massive bodies were forced upward to definite levels, when, being unable to rise higher, they spread out laterally between strata of all ages, from the Cambrian to the Laramie. Centers of powerful intrusion shifted from one locality to another, and within the confined limits of the range batholiths of no mean proportions were forced upward. Evidence is wanting to show that any of these magmas in their upward movement ever penetrated to the surface; apparently they came to a standstill far below a covering of overlying sediments, whose thickness must, for the present at least, remain a matter of conjecture. Excessive erosion since early Eocene time has laid bare these massive batholithic forms, which now stand out as dominant features in the landscape.

There is no evidence to warrant the opinion that these porphyries and crystalline rocks were ever connected with vents discharging lavas, though there is, beyond the boundaries of the Gallatin Range, extravasated material of Eocene age covering large tracts of country. In the northeast corner of the park such surface flows are well developed in the accumulation of silts and ashes. Much of this material was laid down under relatively quiet conditions. Apparently they are much later than the crystalline rocks already referred to, but their age is determined by a characteristic flora corresponding with the well known Fort Union beds of Montana of Eocene age.

In these extravasated lavas the influence of volcanic waters may be recognized in many ways, but degradation of the mass has been so great that evidence of individual extinct hot springs is no longer traceable; moreover, it would seem impossible to distinguish them from those belonging to Miocene eruptions. 


\section{Mrocene Ianeous Rocks and thermal Waters}

The Absaroka Range shuts in the Park Plateau along its eastern border. Strictly speaking, it is not a mountain range, but rather a rugged, deeply dissected tableland, rising from 3,000 to 4,000 feet above the general level of the park. It stretches for 80 miles in a north and south direction and measures nearly 50 miles in width. In strong contrast to the Eocene igneous rocks, this elevated tableland was steadily built up by tumultuous accumulations of breccias, agglomerates, silts, and muds, the products of violent explosive action through numerous conduits from sources now concealed beneath the overlying load. Nearly all phenomena of ejected lavas seen in extinct volcanic areas elsewhere may be observed here. Finally the mass was penetrated by batholithic intrusions, accompanied by innumerable dikes and sills, offshoots from the parent stock. All this was the result of 1ong-continued, protracted energy, as clearly shown both by geological processes and the many successive fossil forests. These flourished through thousands of feet of eruptive material, and were alternately killed by hot fragmentary lavas and preserved by renewed streams of muds and ashes. ${ }^{2}$ The luxuriant vegetation which developed throughout this period is regarded by all paleobotanists as of Miocene age. All volcanic activity long since ceased.

What concerns us most at the present time is the influence of thermal waters, derived from deep-seated subcrustal sources on both the volcanic ejectamenta and crystalline intrusives. The action of these heated waters may be observed equally well on what were surface flows and on the deeply buried intrusive masses. Such surface action may be detected at a number of localities by the presence of alteration products and traces of sediments, although in most cases the latter have been removed by running water. Underground action of subcrustal waters is shown in many places from one end of the range to the other by deposits laid down from ascending igneous emanations in the form of aqueous and gaseous vapors charged with mineral matter. Such deposits consist essentially of quartz, galena, and copper minerals carrying both gold and silver. They lie as contact products along the apophyses of the massive intrusions and never occur far away from them. They were deposited after the crystalline intrusives came to a state of rest, but probably long before they were chilled. It may not be necessary to add, but it should be borne in mind, that at the time of deposition they were much farther below the surface than they are found today. Mining companies have exploited the ores by shifts and tunnels, but so far as I know such

\footnotetext{
${ }^{2}$ Arnold Hagne: Karly Tertiary volcanoes of the Absaroka Range. Presidential address, Geological Society of Washington, 1899. Sclence, -
} 
ore bodies have never proved lucrative, owing to their uncertainty and lack of continuity. Similar ore bodies in the mining regions of Montana and Colorado have been described by Emmons, Lindgren, Weed, Kemp, and others.

Another feature of these intrusive rocks of the Absarokas is seen in the narrow rifts and shrinkage cracks filled with quartz by the ascending currents from deep-seated sources. In like manner the cavities and druses found in the petrified trees of the fossil forests are lined with quartz crystals, due to heated siliceous waters coming up from below. Today there are no hot springs or steam vents to be found in the Absarokas, save in a feeble way on the western flanks, where the ancient breccias have been penetrated by much later rhyolites.

It has seemed necessary to present this somewhat lengthy description of volcanic forces existing in Miocene time in order to bring out in strong contrast the conditions prevailing during Pliocene and recent times.

\section{Pliocene Igneous Rocks and thermal Waters}

After the pouring out of the basic breccias and lavas of the Miocene, volcanic energy, for a time at least, ceased. Atmospheric agencies removed a large body of the surface rocks and carved out drainage channels in the easily disintegrated material. Following a prolonged interval of comparative rest came renewed activity, with marked changes in the nature of the eruptive lavas. Vast masses of rhyolite were extruded, not on preexisting mountains, but over an inclosed basin, converting it into a rugged tableland and submerging the flanks of the bordering ranges. This sharply defined region has been designated as the Park Plateau. It embraces a tract of country 50 by 40 miles, including approximately 2,000 square miles. Strictly speaking, it is not a plateau in the general acceptation of the word, but presents a broken surface accentuated by bold escarpments and abrupt slopes of lava flows. While the topography of the tableland has, to some extent, been modified since Pleistocene time and trenched by ice action, giving the effect of individual plateau blocks, the mass can not be considered otherwise than as a geological unit. The earliest rhyolitic eruptions spread over a very uneven surface, the structural features of which may be fairly well inferred from exposures of sedimentary rocks rising through the surrounding lavas or cropping out from beneath the outer boundaries of the plateau. The rhyolite also lies unconformably on the eroded surfaces of Miocene basic breccias, and not infrequently occupies the older valley bottoms, clearly showing the much later age of the siliceous lavas. Although sharply defined by topographic relief and geological sequence, both periods of ejection are still more 
strongly contrasted by marked differences in the phases of eruption which built up the two volcanic regions.

On the rhyolite plateau there are no evidences of violent explosive action. The complete absence of true voleanic breccias is a significant feature of these later flows. Dikes, veins, and horizontal sills, together with nearly all the phenomena of deep-seated intrusions, are wanting. The rhyolite shows scarcely any indications of hydrothermal activity during eruption. In the abrupt escarpments made up of successive sheets there are no signs of surface flows having been exposed to longcontinued atmospheric agencies, no wind-strewn ashes, or any vestiges of vegetation. On the contrary, everything clearly indicates a relatively rapid accumulation of viscous masses from the beginning to the end of the rhyolite period. What impresses one most is the absence of stages of activity, with intervals of quiescence, there being rather a series of massive eruptions piled up one on another. In the central portion of the park the rhyolites have a maximum thickness of 2,000 feet, and over large areas they may be assumed to measure 1,500 feet.

Subsequent to the rhyolites and the building up of the Park Plateau came a few dikes and thin sheets of basalt. They are the most easterly occurrence of those broad basaltic flows that spread over southern Idaho and the Snake River plain. In the park country they are of Pliocene age-that is to say, they are older than the glacial ice. They make the final chapter in the history of Tertiary igneous rocks. As they play no recognized part in the problems bearing on thermal waters, they may be dismissed at the present time with this brief mention.

Unquestionably the Pleistocene age, with its changed conditions, set in not long after the dying out of rhyolitic eruptions, as is shown by the relatively slight erosion of the plateau and the beginning of canyon sculpturing. All geological evidence tends to prove that the rhyolites belong to the Pliocene age.

\section{Duration of thermal ACtivity}

That the activity of thermal waters was approximately coincident with the cessation of rhyolite ejections is, fortunately, clearly proven by the massive horizontal beds of calcium carbonate laid down on the summit of Terrace Mountain, where they attain a maximum thickness of nearly 250 feet, although the average is much less. Without doubt they are the oldest deposits of travertine in the region of Mammoth Hot Springs, and rest directly on fresh, unaltered rhyolite. Glacial ice from the Gallatin Mountains moving eastward occupied the intervening Swan Lake Valley and passed over the top of Terrace Mountain on its way to the broad, 
open valley of the Yellowstone. On the recession of the glacier fragments of crystalline rocks, undoubtedly brought down from the Gallatin country, were left strewn over the travertine of Terrace Mountain.

It is a fair assumption that if these thermal waters were issuing through rhyolite at one locality in pre-Glacial time, similar hot waters and gaseous emanations should have reached the surface at other points on the plateau. If any such remnants of sinters still remain it seems impossible, from our present knowledge, to discriminate between them and those of post-Glacial time. Erosion has carried away not only every trace of these earlier deposits, but has removed nearly all evidences of pre-Glacial rock decomposition. Modifications in topographical relief fail to indicate two distinct periods, owing probably to the relatively slight deposition of sinter before the ice.

Following the withdrawal of a broad ice-sheet, ascending heated waters, acting with renewed energy on the walls of innumerab]e fissures and rifts, bleached and kaolinized massive blocks of rock. This decomposition of plateau lavas proceeded on a grand scale and left an indelible impression on the rhyolite area. In regard to the age of the hot springs, it is reasonable to conclude that thermal waters were as active at the close of the rhyolite extrusions as at any subsequent period. The antiquity of many localities of decomposed rhyolite is clearly evident, as shown by post-Glacial sculpturing. In certain areas where hydrothermal energy was formerly a long-continued process, evidence of the presence of such sources of heat have long since ceased. No one who has studied the gradual development of these decompositions and metasomatic changes under the influence of acid solfataras, or the deposition of sinter now taking place from alkaline siliceous waters, can doubt the lapse of time required by these geological agents to accomplish the results observed. Such processes can not, however, differ essentially other than in degree from those observed today. In my opinion, they have never ceased to be active and have only varied in intensity from time to time. It meets all the requirements, therefore, for our present purpose, to consider the phenomena now taking place, or since the hot springs and geysers were first brought to the attention of the scientific world, about forty years ago.

\section{Climatic Conditions}

Precipitation of moisture over the plateau and encircling mountains is far heavier than that taking place over the semi-arid regions below. Not only is the rainfall higher for every month of the year, but the temperature is correspondingly lower. Four large rivers-the Yellowstone, 
Snake, Madison, and Gallatin-carry the waters from the uplands to the lowlands. Knowing the amount of water leaving the park by these principal drainage channels, it is easy to estimate approximately the total amount of surface waters carried away.

Meteorological records, more or less complete, have been kept at Mammoth Hot Springs for over a quarter of a century, and during one winter at the Firehole Basin. From these data an approximate estimate can be made of the water falling over the entire region. Some years ago instrumental measurements were undertaken during the summer to determine the amount of evaporation on the open sinter plain in the Upper Geyser Basin. Similar observations were made at the outlet of Yellowstone Lake. Taking into consideration the annual precipitation and run-off and the summer evaporation, I believe the supply of water greatly exceeds the amount carried away by surface streams. Climatic conditions, as they exist in the park today, favor forest development and a varied undergrowth. It is estimated that over 82 per cent of the region is forest-covered. For eight months precipitation occurs in the form of snow, which, protected by the forests from the sun's rays and the drying winds, melts slowly and lingers on well into midsummer. On the adjoining mountains the snow seldom entirely disappears. The retention of the water by forest and undergrowth brings about the development of the many meadows, marshes, and bogs. Scattered over the tableland occur frequent ponds and lakelets, carrying in the aggregate a very considerable body of water. In this connection may be mentioned such large reservoirs as Yellowstone Lake, covering over 125 square miles of surface, and Shoshone Lake, measuring 12 square miles, to say nothing of other picturesque sheets of water of less imposing dimensions, all of which lie on the rhyolite from 500 to 700 feet above the Upper Geyser Basin, where the greatest number of large geysers is found and the activity and overflow of thermal waters displayed on a grand scale. In time much of the water from the meadows and ponds naturally finds its way to surface streams. Another portion is taken up by the luxuriant vegetation or is absorbed by the atmosphere. The remaining water, which constitutes a very considerable volume, is drawn down through openings into underground reservoirs. In other words, these descending waters slowly percolate through the viscous lavas.

\section{Phystcal Structure of Rhyolite}

Returning for a few brief moments to rhyolite flows, let us consider certain physical features due to textural modifications. No region sur- 
passes the Yellowstone Park in the varied phenomena of highly acid extrusions. This is especially true of the more glassy types, and in general a glassy groundmass characterizes most of these lava sheets. $\mathrm{Mr}$. J. P. Iddings has submitted a large series of specimens of the park rhyolites to a searching petrographical investigation, making a special study of the microgranular structure and the relations of the different microstructures to one another, and pointing out the abrupt transitions from the glassy to the crystalline and from the pumiceous to lithoidal forms. For further details the student is referred to this admirable work. In conclusion, Mr. Iddings calls attention to the agency of water in bringing about the varied products. He says: "The heterogeneity of the acid lavas, so far as known, is confined to the distribution of vapors, presumably of water, and suggests that the water thus irregularly disseminated has not existed within the magma long enough to become uniformly diffused. It must therefore be looked upon as water absorbed near the earth's surface." ${ }^{3}$

From the point of view of the present discussion, the cause of these remarkable structural variations concerns us less than the influence exerted by such textural modification in the creation of fissures, fractures, and capillary openings for the percolation of waters. Obsidians, perlites, and pitchstones were poured out over the greater part of the central plateau and may be found at the base of bold escarpments under accumulation of successive flows. Glassy forms present as marked a feature of many of these earlier outpourings as they do of the more recent flows. They were surface flows when ejected. They prove conclusively, on geological evidence, that similar physical conditions were identical from the beginning to the close of the rhyolite phase of eruption. The liquidity of the magma and its crystallization change from time to time, being dependent on varying causes, such as the degree of temperature when ejected from the point of discharge, the volume of the mass, and the power of the lava to hold its contained heat.

Banded and laminated lavas, contact surfaces between magmas of different physical properties, shrinkage cracks and jointings in obsidian and perlite, overlapping of lava flows, all caused numerous capillary spaces in the rock. Some of these openings for short distances lie parallel with the lava flows; others are vertical along planes of jointing, while still others indicate great irregularity, broadening and contracting along a circuitous course. Uniting below the surface they develop into wider channels, affording free circulation of either descending or ascending waters.

J. P. Iddings : Geology of the Yellowstone Natlonal Park. Monograph XXXII, part U. p. $\mathbf{1 2 6 .}$ 


\section{Mineral and chemical Composition of Rhyolite}

As I hope to be able to show that the mineral matter brought to the surface in solution by ascending thermal waters circulating through rhyolite is mainly derived from these lavas, it is necessary to examine in detail both their chemical and mineral composition. The chemical composition of the rhyolite appears remarkably uniform when the enormous bulk is considered and the different physical conditions under which the lava streams were extravasated.

In the subjoined table will be found analyses of eleven specimens of rhyolite, arranged according to their tenure of silica. They were made in the laboratory of the United States Geological Survey, but are here brought together in tabular form.

In five analyses the range in silica falls within seven-tenths of one per cent. Lime and magnesia show the greatest variation, while the alkalies do not appear to be higher than in many other localities where rhyolite has been extravasated in the form of massive eruptions. Titanic oxide has been determined in small amounts, but was not detected in the obsidians or in any of the extreme glassy rocks. On.the other hand, both sulphuric acid and chlorine occur in small quantities in the fresh glassy varieties, but, curiously, analysis fails to show the presence of both in the same flow. Traces of manganese have been detected in many specimens from widely separated parts of the tableland, which is interesting from the fact that in one or two localities solfataras have deposited manganese oxide as dendritic incrustations. Considering the rhyolite as a homogeneous mass, the composition of the molten magma is probably best shown in the specimen from Madison Canyon. Here the silica percentage was 75.2 per cent, the alumina $13.7 \%$, and the combined potash and soda 7.16.

As regards mineral composition the rhyolite is by no means as simple; owing to textural modifications that range from semitransparent, amorphous obsidian, to liparite, with relatively little groundmass. Nevertheless, the species that have crystallized out from the magma are few in number, the only essential rock-making minerals being quartz and sanidine. In certain lavas quartz, in irregular crystals, occurs abundantly disseminated as megascopic phenocrysts, while in others it is wholly wanting. Plagioclase stands next in order, being easily recognized in many thin sections under the microscope, although being seldom recognized by the naked eye. 'This is probably owing to the small amount of alkaline earths present. Small flakes of biotite have been detected here and there, but in the typical rhyolite it may be said to be absent. Pyroxenic minerals are rare and only in microscopic crystals. Magnetite is 


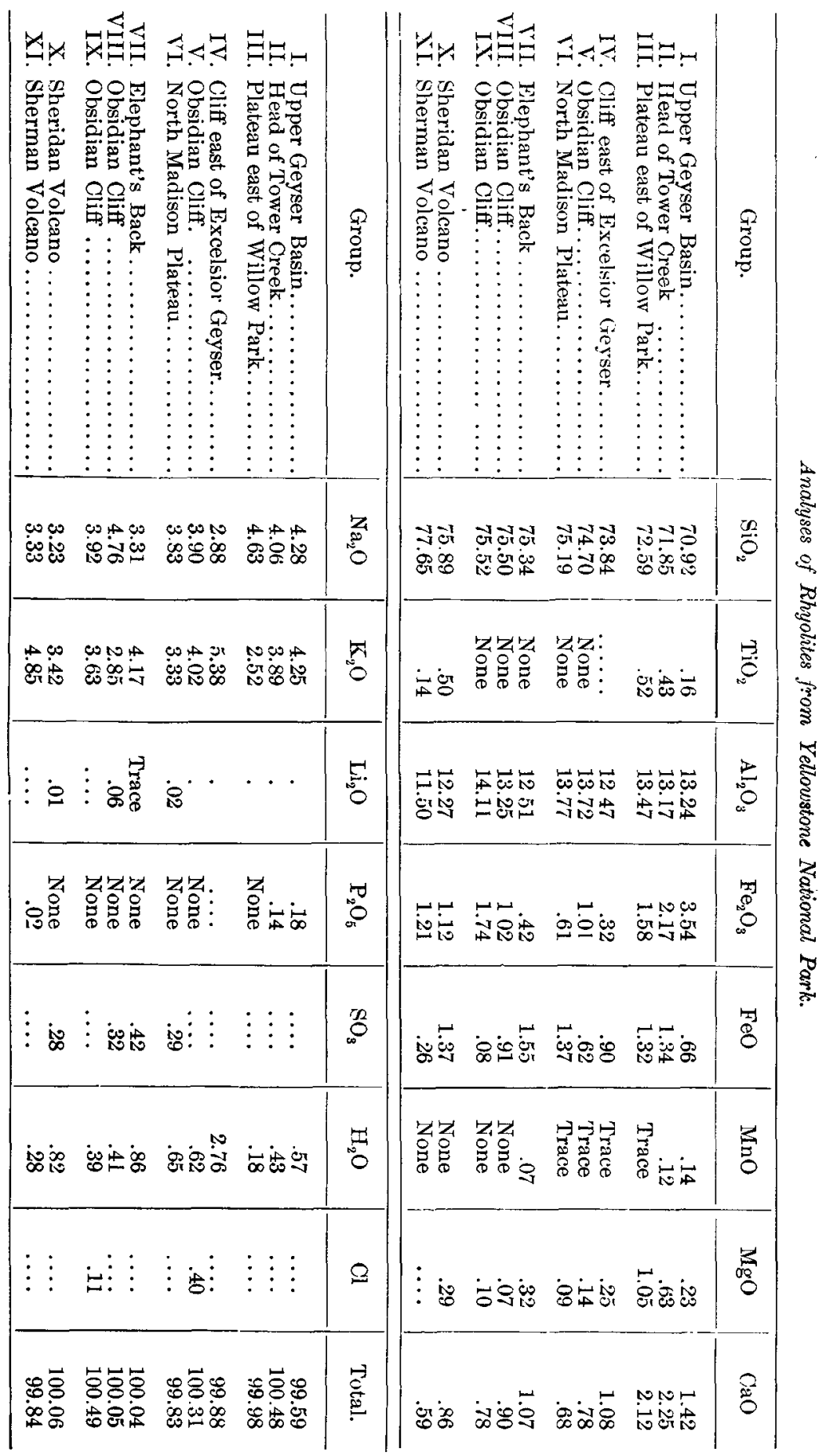


somewhat more widely distributed, but only in minute grains, as might be supposed from the low percentage of iron oxides. The presence of titanium in the magma reveals itself in the disseminated grains of ilmenite and pseudobrookite. Apatite, zircon, and allanite complete the limited list of accessory minerals.

\section{Classification and Composition of thermal Springs}

The number of springs scattered over the park, from which flow varying amounts of thermal waters, probably exceed twenty-five hundred. If to these be added the fumaroles, solfataras, and narrow rifts, from which issue steam and gaseous emanations, mingled with more or less water, the number would be greatly augmented. It is impossible to enumerate them, as new ones are frequently reaching the surface, while others are slowly becoming extinct. Furthermore, it would be no easy task to decide whether single points of discharge should be counted or considered as a group having a common source a short distance below ground. These thermal waters reach the surface holding mineral matter in solution, derived from the decomposition of rocks through which they pass in their upward movement. They may be arranged under four heads:

1. Waters carrying calcic carbonate in solution.

2. Siliceous alkaline waters rich in dissolved silica.

3. Calcic siliceous waters having both properties of calcic carbonate and siliceous alkaline springs.

4. Siliceous acid waters, usually holding free acid in solution.

Nearly thirty of these thermal waters have been analyzed by F. E: Gooch and J. E. Whitfield in the laboratory of the United States Geological Survey and the results published in a separate bulletin. ${ }^{4}$

Among these waters are several from the Mammoth Hot Springs characterized by the large amount of calcic carbonate in solution, associated with free carbon dioxide and sulphates of magnesium and the alkalies. Underground conditions were doubtless favorable for holding in solution large amounts of calcic carbonate. With the relief of pressure at the surface and the diffusion of free carbon dioxide, precipitation followed, as shown in the deposits which have made the Mammoth Hot Springs so famous. From the present point of view we are not so much concerned with depositions from these waters as with the waters themselves and their geological relations, since they unquestionably have a common source with those of the rhyolite plateau.

At the Mammoth Hot Springs the upper lava flows lie directly against

F. A. Gooch and J. E. Whitfleld: Analyses of waters of Yellowstone National Park. Bulletin of the U. S. Geological Survey, No. 47, Washington. 
inclined Jurassic limestones. The circulating hot waters having been diverted in their course traverse the limestone before issuing at the surface. Apparently the waters derive a large part of their mineral constituents from the limestone. In contrast to the hot waters of the plateaus they carry but little silica in solution. Far to the southward, where the rhyolite tableland ends, the attenuated lava streams also rest against uplifted limestones. Calcic carbonate springs, although of modest dimension, issue through the rhyolite, but have derived their mineral contents mainly from the adjacent limestones. Both the carbonated waters and the travertine deposits resemble those at Mammoth Hot Springs. Similar geological relations may be observed near the eastern limits of the rhyolite at Soda Butte Spring, and again near the western border.

On the other hand, wherever the heated waters issue from the rhyolite of the tableland they are characterized by a high percentage of silica. These waters occur distributed over a wide area and furnish the great volume of water discharged from the geysers and hot springs, and for this reason have excited more general interest than the smaller springs. They have supplied the silica for the many square miles of glittering white sinter plains. For the most part they are siliceous alkaline waters, as in the Upper Geyser Basin and the Firehole Basin. They, however, may be slightly acid or neutral, as in the case of many of them in Norris Basin.

The silica occurs in solution as hydrated silica associated with carbonates and chlorides of the alkalies, together with small quantities of sulphates. Arsenic and boron have been determined in nearly all geyser waters, probably combined with soda as arsenates and borates. Traces of bromine, phosphoric acid, soda, manganese, lithium, caesium, and rubidium were detected in several instances, but lithium and bromine are the only elements present in sufficient quantities to allow of estimation. Tests were made for titanic acid, nitric acid, iodine, fluorine, barium, and strontium, but none of them were found. Special examinations were made in concentrated solution for tin, copper, and lead, but no one of them was present. In this connection it may be pointed out that while veins carrying lead, copper, and silver are found associated with Eocene and Miocene igneous rocks, these metals have never been detected in either the rhyolite or waters of the park.

A study of these chemical analyses brings out clearly the marked differences in percentages of substances held in solution, especially silica, even in adjoining geysers. This holds equally well for the siliceous alkaline waters from the same geyser basin as from those collected from different localities. Waters examined the same year show as great variations as those collected one or two years apart. The silica, as determined by 
analysis, ranges from .22 to .67 grams per kilogram of water, the former being the amount found in the cauldron of the Excelsior, having the largest outflow of any pool in the park, and the latter from Opal Spring in Norris Basin, with but slight run-off and without any apparent inflow. The cause of these differences is, I believe, to be sought in the varying amounts of infiltrating surface water.

Dr. W. H. Hallock has shown conclusively, by experimental tests with self-registering thermometers, that the thermal waters stored in underground geyser reservoirs possess a temperature far in excess of the boiling point at the surface, due to increased pressure of the overlying column of water in the geyser tube. The results were in accord with the theoretical boiling point. It can not be affirmed positively that these superheated waters maintain the same composition after being thrown out as the underground waters at greater or less depth or even with those of the geyser reservoirs. On the other hand, there exists no evidence of chemical changes due to relief of pressure before the waters reach the surface through geyser orifices.

On the relief of pressure, hydrated silica, associated with traces of an equally insoluble silicate of alumina and lime, is deposited on the broad plains of the geyser basins. Nearly all remaining constituents are carried away in solution by surface streams. Although the composition of the deposited sediment is everywhere much the same, its external habit varies with the manner of its secretion, which may have happened in several ways. It may have been caused by precipitation on relief of pressure, precipitation on cooling, separation by evaporation, and assimilation by algæ. Mr. Walter H. Weed has shown conclusively the important part such organisms perform as geological agents in the accumulation of sinter deposits. ${ }^{\mathrm{s}}$

The volume of siliceous alkaline waters far exceeds those of the acid type. On the other hand, the latter occur more widely distributed, are more complex in their composition, and consequently more varied in their deposits. These acid waters come to the surface through fumaroles, solfataras, and the so-called mud springs and paint pots. In nearly all such occurrences the waters carry either free hydrochloric or sulphuric acid. In general these thermal waters, which rise through narrow seams and rifts, run but little water and leave behind only thin incrustations a:ound the sources of supply. These deposits are found widespread over the park and consist principally of sulphates of alumina and double compounds of alumina and iron. While they show a mingling of saline

5 Witer H. Weed: Formation of travertine and stliceous sinter by the vegetation of hot springs. U. S. Geological Survey, Ninth Annual Report, Washington, 1890. 
compounds carrying more or less silica as an impurity, the number of mineral species remains singularly few. Halotrichite, alunogen, and alum are the only minerals of the alum group determined. In the far more arid regions of New Mexico accumulations of these minerals have been described by Dr. C. W. Hayes ${ }^{\natural}$ as deposits from aqueous solutions associated with igneous rocks.

Under quite different conditions, and as thin layers deposited below water level in the Norris Basin, occur incrustations of both sulphides of arsenic, orpiment and realgar. They are, however, very restricted in quantity. Scorodite, delicate crystals of sulphur, and ochreous deposits, mainly ferric oxide and silica, are characteristic of certain acid and neu= tral waters. These sediments and incrustations point clearly to different conditions of thermal activity. In strong contrast from those described in connection with siliceous alkaline waters, they indicate an earlier stage in the development of rock decomposition.

\section{Gases from thermal Springs}

Several years ago gases emitted from many of the springs were collected and submitted to analysis by Prof. F. C. Phillips, of Pittsburg. They were all found to carry carbon dioxide, oxygen, hydrogen, and nitrogen, but to vary greatly in relative amounts. In general, those from Mammoth Hot Springs, where the waters issue through limestones, are characterized by carbon dioxide, one analysis from the spring on the main terrace holding no less than 98.68 per cent of the gas. Those from the upper basin, which issue directly from the rhyolite, consist principally of nitrogen, the Artemesia Geyser carrying 95.08 per cent of the latter gas. Traces of methane were found in several waters. Hydrogen sulphide was only detected in two samples, and in neither of these did the gas amount to one per cent of the gaseous content. One of these was from a sulphur spring in the Mammoth Hot Spring Basin and the other from the Shoshone Geyser Basin. In none of the waters from the geysers and large hot springs in the three principal basins was any hydrogen sulphide detected.

Professor Phillips says: "There is, in fact, a curious gradation between analyses from No. 1 and No. 10, as regards the proportion of nitrogen and carbon dioxide. Oxygen is present in all of them, and as ten of these gases contain combustible elements, hydrogen and methane, it is evident that the gas as it escapes from the spring has not been exposed to a high temperature."

It is admitted by most authors that under certain conditions all these

- Dr. C. W. Hayes : Bulletin of the U. S. Geological Survey, No. 315, 1905, pp. 215-223. 
gases may be contained in surface waters. I think it has been shown that under the peculiar conditions in which these waters occur and their lack of uniformity of composition they must be considered as absorbed by vadose waters.

One of the most marked characteristics and one of geological significance is the frequent variation shown in temperature, flow, and salinity of the thermal waters where they issue from the rhyolite plateau. The solvent power of water holding mineral matter in solution is, as is well known, far greater than that of pure water. Now the downward percolating waters gather material from the disintegrated rhyolite soil and in some measure from the soluble salts previously brought up from below. There is also a certain amount of carbon dioxide derived from the atmosphere. It is a fair assumption, therefore, that in percolating downward the waters carry with them to the water level below no inconsiderable amount of material.

The ascending superheated waters, under pressure, exert a far greater influence. The work done by these waters, and that which is still going on, is self-evident even to the most casual tourist. It is shown by the broad areas and ridges of altered and bleached rhyolite. Nowhere is this more in evidence than in the escarpments along the Grand Canyon of the Yellowstone, where the gorgeous coloring is due to the oxidation of the ferruginous minerals. The potent influence of such waters under existing conditions can hardly be questioned. They readily attack both the glassy groundmass and crystalline feldspars of the rhyolite, and when the metasomatic changes are complete they leave behind an impure kaolinized material mixed with quartz and held together by colloidal silica.

\section{Development of Springs and Geysers}

The ascending waters, in their circuitous course, penetrate fresh seams and cracks in unaltered rock, which slowly widen under the disintegrating influences of aqueous vapors. Finally the thermal waters, following these cracks, issue at the surface as hot springs and pools. The early waters are usually acid in composition and deposit ferric and aluminous salts. Occasionally they set free sulphur, derived from the decomposition of hydrogen sulphide. In time the openings through which they flow become broader, the waters themselves, free from hydrogen sulphide, become clearer and neutral, and at last issue as siliceous alkaline waters. Underground reservoirs are excavated and become sources of hot springs and, under favorable conditions, geysers. The geyser itself is simply a stage in the development of geological processes. In time geysers themselves become extinct. New geysers break out and, given the essential physical conditions, may develop eruptions quite as fine as any in action 
at the present time. Geologically speaking, the final stage of thermal activity is a hot spring. The tendency of a geyser is to develop a hot surface pool. If from such pools there is discharged a sufficient amount of overfiow, and if from the surface of these geyser pools there is an ample dissipation of heat into the surrounding atmosphere, explosive action may cease and the geyser, as such, may become extinct. It is frequently stated that some geyser has ceased to be active, and that this indicates the slow dissipation of the original source of heat. This I believe to be an error. The change is simply due to a shifting of the channel of the ascending waters.

If, on the other hand, there should be marked climatic changes and arid conditions should set in over the park and adjoining mountains, in my opinion, thermal springs would become extinct. Should this happen it would be evident beyond all question that the waters were derived from vadose sources. Again, with the disintegration of lavas and the building up and enlargement of reservoirs, existing conditions of hydrostatic pressure would cease and the circulating waters, unable to rise, would distribute themselves laterally; in which case there might break out at the base of the rhyolite plateau calcic springs such as we now find and have already described.

In all probability the magnitude of a geyser is, in a measure, dependent on the size of the underground reservoir, or series of reservoirs, produced by the disintegration of lavas along channels of ascending waters. It has been demonstrated by self-registering thermometers that cool infiltrating waters may drain into partially erupted reservoirs after geyser eruption. This has been shown in the case of the Giantess Geyser. The question was once asked by an attendant at the hotel, who had spent several summers in the park, why Old Faithful was more apt to be several minutes behind time in September than in July. I am not aware that such a condition was ever established, but if so, my reply would be that in the autumn the infiltration of surface waters is not as rapid as in early summer; hence a retarding of the eruption by several minutes.

It is probable that the Norris Geyser Basin, in its thermal development, is later than the Upper Geyser Basin. In the former are found the early and more acid conditions; the waters of the geysers are mainly neutral and form deposits of arsenical sulphides, alum, and ferric salts. These phenomena are for the most part absent in the Upper Geyser Basin, where the waters have reached a more advanced stage and possess a siliceous alkaline composition.

With the exception of arsenic and boron, which occur in minute quantities, all the elements brought to the surface in solution by the thermal waters of the park have been found in the rhyolite. In this connection 
it may be said, and it is generally accepted by those who have studied the region, that the mineral waters of Pfaeffers, in the Tyrol, have a vadose origin, and analyses show that both these elements are present. ${ }^{7}$ Both these elements are found associated together in many thermal waters of Europe. Not only is it true that, with these exceptions, all the elements are accounted for in the rocks, but the proportion of the ingredients in the waters bears a remarkable relation to that of the elements in the rhyolite itself. Silica and the alkalies are the predominating elements. Even lithia, which is a feature of many siliceous lavas, has been quantitatively estimated in all these thermal waters. The water from old Faithful yielded .0056 of a gram per kilogram of water, which, according to the theoretical composition, shows that lithium chloride forms 2.44 per cent of the amount of material held in solution. The neighboring Giantess Geyser carried precisely the same amount of lithium chloride. The low percentage of iron, manganese, lime, and magnesia contained in the ascending waters is readily accounted for by the comparatively small quantities of these elements in the glassy rhyolite through which these waters pass.

The circulating ascending waters may, to some extent, be charged by foreign substances other than by superheated aqueous vapors. Nevertheless, in the park country the vadose ascending waters do not appear to have been greatly affected by any primitive, deep-seated waters or their contents. Even if foreign mineral matter were present it does not follow that the material was not taken up originally by vadose waters.

In Iceland geological conditions are apparently quite different, and volcanic eruptions may be said, geologically speaking, to be still going on, in strong contrast to the Yellowstone Park, where such action ceased many thousand years ago. In Iceland the thermal waters are, in my opinion, mainly vadose, and their heat derived from sources not far below the surface. ${ }^{8}$

I agree with Dr. Rudolf Delkeskamp ${ }^{\theta}$ that temperature, included gases, and salinity in many localities are not in themselves conclusive evidence of the source of thermal waters, and that far safer criteria for the determination of the primitive origin of waters are to be sought in uniformity of flow and chemical composition. What I wish to emphasize, however, is that the thermal waters of the Yellowstone National Park are charac-

TM. De Launay : Annales des Mines, February, 1894.

Bince presenting this address I have recelved from Dr. Thorkell Thorkelason, of Copenhagen, a cops of a suggestive paper on "The hot springs of Iceland," which conflrms me In the opinion of the vadose origin of the Iceland thermal waters. Dr. Thorkell's paper appears as a recent publication forming one of the Memoires de l'Academle Royale des Sciences et des Lettres de Danemark. Copenhague, 1910.

- Juvenile und vadose quellen, Balneologischen Zeltung, XVI, Jahrgang, No. 5, 1906. 
terized by frequent variations of temperature, progressive transitions in chemical composition, lack of uniformity in mode of occurrence, and shifting in points of discharge; in other words, they lack the essential characters of primitive waters derived from deep-seated sources.

\section{RADIOACTIVITY OF THERMAL WATERS}

Throughout this paper in the discussion of the geological relations of the thermal waters to the rhyolite eruptions laboratory investigations bearing on the composition of the rocks, waters, sediments, and gases have been utilized. In the discussion of the circulation of descending and ascending waters almost nothing has been said in relation to the source of heat which raised the temperature of these waters. This is in part due to the fact that the problems involved are in a great measure distinct from those treated here, and time does not permit of their consideration, and in part because I know little about the matter. My opinions are still open to conviction. With this avowal I may be allowed to add that $I$ am reluctant to believe that the source of the heated waters is, geologically speaking, deep seated or subcrustal.

In this connection it might not be out of place to mention the investigations of Prof. Herman Schlundt and R. B. Moore on the radioactivity of the thermal waters of Yellowstone National Park, conducted under the auspices of the United States Geological Survey and recently published. ${ }^{10}$ They found the rhyolites, limestones, thermal waters, gases, and sediments to be radioactive. Specimens of rhyolite from widely separated localities in the park were examined. These authors say:

"These data certainly seem to indicate that the hydro-thermal activity so manifest in the park is not connected with localized deposits of radium. In the above calculations the question of heat lost by diffusion and other factors is not taken into consideration, but after allowing a generous margin for error we do not see how more than one per cent of the heat required for the hydrothermal action can be ascribed to the radium content of the rocks."

Recently deposited travertine at the Mammoth Hot Springs, as well as that of the Main Terrace and from the preglacial capping on Terrace Mountain, was subjected to similar tests. The same authors say:

"The travertine of Terrace Mountain is overlain by glacial boulders. Since its activity is only one per cent of the recent deposits, its age is about 20,000 years, which would also be the approximate time that has elapsed since the glacial period in the park."

Furthermore, a sample of the Jurassic limestone underlying the Mammoth Hot Springs proved to be more radioactive than the most active

\footnotetext{
10 The radioactivity of the thermal waters of the Yellowstone National Park. $u$. $\mathbf{s .}$ Geological Survey Bulletin, 1909, p. 395.
} 
sedimentary rocks tested by that eminent authority, R. J. Strutt, of England. It is noteworthy that the latter rocks referred to were specimens of the oölite formation from near the celebrated springs of Bath.

Strutt has also pointed out that siliceous igneous rocks are more radioactive than basic lavas, ${ }^{11}$ a highly significant observation when it is borne in mind that the rhyolite of the Yellowstone National Park stands preeminent as an acid, crystalline rock. Iddings and Cross ${ }^{12}$ have shown that allanite in microscopic crystals is widely but sparsely distributed in the siliceous igneous rocks of the Rocky Mountains, and has been detected in the rhyolite of Yellowstone National Park. Now allanite is known to carry small quantities of thorium. It is a coincidence worthy of note that thorium emanation was determined in several of the hot pools, it being first observed in this country in thermal waters in an obscure hot spring in Norris Basin. I see no reason, however, to doubt the conclusions of Messrs. Schlundt and Moore that the heat produced by radioactive emanation from the rocks and waters is wholly inadequate to meet the requirements. It seems necessary, at least from our present knowledge, to look elsewhere for the source of the heat dissipated by the thermal waters of the Yellowstone Park.

\section{SUMMARY}

In conclusion I may state that I have attempted to show: (1) that igneous activity was continued throughout Tertiary time; (2) that this activity came to an end with the close of Pliocene time; (3) that during the Eocene and Miocene deep-seated waters were active geological agents, and that these waters were essentially primitive in their origin; (4) that in strong contrast to the explosive, volcanic conditions of the Miocene, the Pliocene lavas were emitted under far quieter conditions and built up the successive flows that formed the rhyolite plateau; (5) that during the many thousand years since the withdrawal of glacial ice the Pliocene rhyolites have, since the beginning of Pleistocene time, been steadily undergoing progressive changes, brought about by the action of enormous volumes of superheated vadose waters; (6) that the gases contained in the thermal waters were in great measure derived from vadose sources: (7) that the eruptions and periodicity of geysers are phenomena due essentially to varying conditions of reservoirs and channels of superheated waters situated only short distances below the surface; (8) that the phenomena as seen today represent a phase in the evolution of thermal springs.

11 I. J. Strutt: On the distribution of radium in the earth's crust and on the earth's internal heat. Proceedings of the Ropal Society, ser. A, vol. LXXVII, 1906, p. 479.

19 Jos. P. Iddings and Whitman Cross : American Journal of Sclence, 3d ser., vol. 80, August, 1885, p. 108. 